\title{
忘却機構をもつ適応的学習のための ニューラルネットワーク
}

$\begin{array}{lllll}\text { 正員 須 } & \text { 貝 } & \text { 康 } & \text { 雄 } & \text { (千葉大) } \\ \text { 非会員 小 } & \text { 林 } & & \text { 賢 } & \text { (日 立) }\end{array}$

\section{A Neural Network for Adaptive Learning with Mechanism of Forgetting}

Yasuo Sugai, Member (Chiba University), Ken Kobayashi, Non-member (Hitachi, Ltd.)

\begin{abstract}
Although there are some neural network models which show adaptive self-organizing characteristics, they have complicated architectures and complicated actions, and there comes to be many parameters which the values are very difficult to be adjusted.

In this paper, we propose a new neural network model for adaptive learning by unsupervised learning. The model consists of simple architecture and so has simple action compared with others. Learning of analog input is also possible by only one representation of input vectors. Moreover, by changing the parameter value, we can make the model forget old patterns. Simulation results indicate the effectiveness of the proposed model.
\end{abstract}

\section{1.まえがき}

これまで提案されてきたニューラルネットワークモ デルの多くは，実際に利用される以前に学㖬期間を経 る必要があり，しかも，学習の前にあらかじめ学習さ せたいデータ（あるいは学習対象を特徵付けるデー 夕)をす心て用意する必要があるうえ，学習時には何 度も繰返し提示する必要がある。また，学習させたい データを追加する場合には，学習を最初からやり直す 必要があったり，新しい記憶のために以前に記憶して いた内容が破壤されるという問題，あるいは学習自体 の収束性という問題もある。

これに対して人間は，過去に覚えた事象を忘れるこ となく，新しい事柄をわずか数回の刺激で記憶する能 力を有する。その一方で，一度覚えたことでも長期に わたり刺激がないと，その事象を态れてしまうことが ある。このことは, 学㿢, 記憶, 認識などは別々に行 われるものではないこと，そして，十分な学習は，確 かな記憶八と結び付くが，短時間の学留でも相応の記 憶が可能であること示している。更に，不必要な事 柄をある意味で積極的に忘机るということは，ニュー ラルネットの記嬑容量を効率的に利用するという観点
から重要であると考えられる。

最近になり，人間のこの適応能力に着目して，それ に類似した機能をもつニューラルネットワータモデル が提案されてきた(1) (3)。これらのモデルでは，ネッ トワークは既に記憶した内容を破壊することなしに， 新しい入力データを記憶することができ，学習に必要 なデータの提示回数も従来のネットワータ学習法に対 してはるかに少なくなっている。

Grossberg 0 ART (Adaptive Resonance Theory $)^{(1)(2)}$ は，人間の適応能力に着目したニューラ ルネットワークモデルである。しかし，構成が複雑で ネットワークの内部に双方向の結合が存在するため, 動作も複雑である。また，山内らのモデル(3)は， ART と比較するとネットワークの構成は簡単である が，学習時に必要なパラメータの数が数個あり，その 設定も難しい，といった欠点がある。

そこで本論文では，従来とは異なる手法により，提 示された入力デー夕を遂次適応的に教師なしで学習す るニューラルネットワークモデルを提案する。このネ ットワークは従来のモデルに比べて構成や動作が簡単 である。また,アナログの入力データを学習でき, 学 習の際のデータの提示回数も一度ですむ, 学習と認 


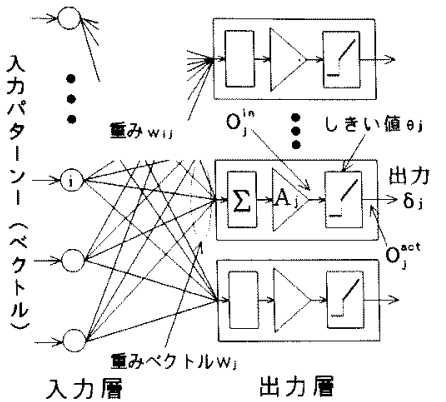

図 1 ネットワークの構成

Fig. 1. The network architecture

識・分類は同時に行われる，などの特徵をもつ。更に， パラメータの設定を変えることにより，人間のように 長い間提示がないと学習した内容を徐々に忘却させる ことも可能である。

本諭文では，まず第 2 章で提案するネットワークモ デルの構成を示し，第 3 章でその動作を述べる。第 4 章ではネットワークの学習について, その原理も含め て説明する。最後に第 5 章では数種の実験を行い, 本 モデルの有効性を検証する。

\section{2. ネットワークの構成}

図 1 にネットワークの構成を示す。ネットワークは 入力層と出力膡の 2 層加らる。入力層のユニット数 を $n$, 出力層のュニット数を $m$ とすると, 入力層の ユニット $i(i=1, \cdots, n)$ と出力層のコニットj(j=1, $\cdots, m)$ との問は, 重み $w_{2 j}$ で結合されている。出力尿 のニニットでは，入力信号が増幅され，増幅された信 号が出力ユニットへの入力値として取り入られる。ま た，出力層のュニットにはしきい值 $\theta_{j}$ が存在する。

出力層のユニットの各々は，入力データを分類する クラスに相当している。入力層一出力層間の重み $w_{i j}$ には，学習により入力データが記憶されていき，同じ もしくは類似のデータが数多く提示されるほど，その 值は大きくなる。出力層ユニットjでは，入力層ユ二 ットからの信号が增幅される。その増幅率を $A_{j}(j=$ $1, \cdots, m)$ で表す。この増愊は, 出力ュニットの奏際 の出力を決定する信号量を調節する働きをつ。しき い值 $\theta_{j}(j=1, \cdots, m)$ は，提示したデー夕が記憶され ている内容に類似であるかどうかを決定する働きをも ว。

\section{3. ネットワークの動作}

ネットワークの動作は, 通常の層構造二ューラルネ

電学論 $C, 113$ 巻 6 号, 平成 5 年

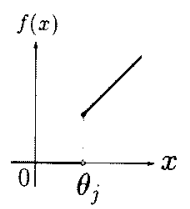

(a) $\theta_{s} \neq 0$

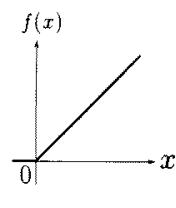

(b) $\theta_{j}=0$
図 2 関数 $f(x)$ の入出力特性

Fig. 2. Characteristics of $f(x)$.

ットワークと同様，入力層に入力データを提示すると これが信号となり，重みを通じて出力層に伝搬し，最 終的に出力層のユニットから何らかの值が出力され る。

本采ットワークに，要素が実数の一般的な $n$ 次元 ベクトルを入力データとして提示する際には，提示の 前にその大きさが 1 となるように正規化して扔く。正 規化された入力データ $I=\left(I_{1}, I_{2}, \cdots, I_{n}\right)$ (以下，これ を単にパターンI と略記する) を入力層に提示する と, 出力層のュニット $j$ には, 重み付き和が入力さ れ，その信号がュニット内で增幅率 $A_{j}$ で増幅され る。従って, 出力層のュニット $j$ の増幅後の入力 $O_{j}^{\mathrm{m}}$ は次式のようになる。

$$
O_{j}^{\mathrm{ln}}=A_{j} \sum_{i=1}^{n} w_{i j} I_{i} \quad(j=1, \cdots, m)
$$

(1)式の $O_{j}^{\mathrm{ln}}$ が実躓的な出力ュニットjへの入力にな る。以後, 出力ユニットへの入力という表現は,この $O_{j}^{\mathrm{tn}}$ を意味するものとする。また，出力層の内部活性 值 $O_{j}^{\mathrm{act}}$ は，次式による。

$$
O_{j}^{\text {act }}=f\left(O_{i}^{\text {in }}\right) \quad(j=1, \cdots, m) \text {. }
$$

ただ,

$$
f(x)= \begin{cases}x & \left(x \geqq \theta_{j}\right) \\ 0 & \left(x<\theta_{j}\right)\end{cases}
$$

(3)式は，アナログしきい值関数と同様に入力がし きい值を超えなければ出力が0である。しかし，アナ ログしきい値関数では，入力がしきい值を超えていれ ば，超えた分を出力するが，(3)式の関数は，図 20 ようにしきい值を超えた場合には，入力をそのまま出 招す。

出力層のユニット間では競合 ${ }^{(4)(5)}$ が行われ，最も大 きな内部活性值をとるユニットが勝者となる。競合学 習においては，図1に示した層間の結合以外に，出力 層のュニット間に相互抑制の結合（側方向抑制結合） がありそれらの結合の働きにより自動的に一つの工 ニットが活性になり，その他のュニットが不活性にな る(6)。本モデルでも, 出力潧のユニット間に相互扣制 結合があることを仮定してもよい。しかしながら，本 
論文の目的は、ニューラルネットの特徴である分散並 列処理を，ハード的に実現するというよりも，むし ろ，その利点を利用することを主としているので，害 際には，最大の内部活性值を有する出力ユニットをネ ットワーク外で論理的に選択している。ここでは, 通 常の記述の仕方に徒って, 最大の内部活性值を有する 出力ュニットを見つける過程を競合と呼び，その出力 ユニットを勝者と呼ぶことにする。競合に勝ったュ二 ットは, 出力 $\delta_{j}=1$ を, そ扎以外のユニットは $\delta_{j}=0$ を出す。すなわち，次式のようになる。

$$
\delta_{j}= \begin{cases}1 & \text { if } O_{j}^{\text {act }}=\max _{j=1 \cdots m}\left\{O_{j}^{\text {act }}\right\} \\ 0 & \text { otherwise }\end{cases}
$$

以上がネットワークにパターンを提示したときの動 作であるが，パターンが提示されていないときには， ネットワークの全ュニットの状態は 0 となり, 出力層 のユニット間での競合も起こり得ないので, 出力層の ユニットの出力 $\delta_{j}$ すべて 0 となる。

\section{4. ネットワークの学習}

以下では，出力層のユニットおよびそれに付随する 重みが何も学習していない状態在“未学習状態（初期 状態)”，何らかのパターンを学習している状態を“学 習状態”，学習したパターンを忘れていく状態を“忘 却状態”と呼孞ことにする。

〈4・1〉ネットワークの学習法本ネットワーク では,パターンを記憶するという学習を, 重み $w_{i j}$, 堌幅率 $A_{j}$ 古よびしきい值 $\theta_{j}$ の值を修正することに より行う。また，学習の特徴としては，一度ネットワ ークにパターンを提示するたけけで学習が終了するとい うことが挙げられる。末知のパターンをネットワーク に提示すると，競合により末学習コニットの一つが選 択され，次式に従い学習が行われる。

重み $w_{i j}$

$$
\begin{aligned}
\text { for } & \forall i, w_{i j}(t+1) \\
= & {\left[1-\alpha g\left\{\theta_{j}(t)\right\}\right] w_{i j}(t)+\delta_{j} I_{i} }
\end{aligned}
$$

堌幅率 $A_{j}$ :

$$
\text { for } \forall j, A_{j}(t+1)=h\left(1 /\left|\boldsymbol{W}_{j}(t+1)\right|\right)
$$

ただし，

$$
h(x)= \begin{cases}x & (x \leqq \text { BOUND }) \\ \text { BOUND } & (x>\text { BOUND })\end{cases}
$$

$$
\left|\boldsymbol{W}_{j}(t+1)\right|=\sqrt{\sum_{i=1}^{n}\left\{w_{i j}(t+1)\right\}^{2}}
$$

しきい值 $\theta_{j}$

$$
\text { for } \forall j, \theta_{j}(t+1)
$$

$$
=\left\{\begin{array}{cc}
(1-\alpha) \theta_{j}(t) & \text { if } A_{j}(t+1)=\mathrm{BOUND}, \\
\delta_{j}=0 & \text { otherwise }
\end{array}\right.
$$

ここで, (10)式の類似度 $s$ は $0<s<10$ 定数であ り，その值が大きいほど入力パターンを多くのクラス に分割する。また $(5)$ 式の忘却定数 $\alpha(0 \leqq \alpha<1)$ は, $\alpha=0$ のときは学習したパターンを忘れないが, $\alpha>0$ のときにはその值が大きいほど学習したパターンを忘 れやすい。従って, 類似度 $s$ は入力パターン集合を幾 つのカテゴリーに分類するかに対応し，忘却定数 $\alpha$ は忘却の速さを特徵付ける。これら二つの定数の值は 学習結果に大きな影響を与えるが，ある目的のネット ワークを構成する際，現状では試行錯詰によりそれら の值を决定する必要がある。

一つのパターンIを一度だけネットワークに提示 し、このパターンIに反応した（競合に勝った）出 力ュニットjの増幅率 $A_{j}$ は，学畾によりその値がほ 球 1 となるが，その後忘却により值が徐々に大きくな る特性がある。その理由は, 重み $w_{i j}$ の初期值は非常 に小さな值であるため(後述)，学習後の重み $w_{i j}$ の 值は (5)式の右辺第 2 項でほほ決定される。パターン Iの大きさは，あらかじめ大きさ 1 に規格化されてい るので，学習後の重みベクトルの大きさもほほ1にな り，（7）式より学習後の増幅率 $A$, の值もほほ 1 にな る。また，忘却により重みべクトルの大きさが小さく なると，(7)式より，増偪率 $A_{i}$ の值は逆に大きくな る。(8)，(10)式のBOUND は, 忘却の開始時期を 定める 1 より大きな正定数であり，これにより増幅率 $A_{j}$ の変化量の上限值を決定している。学習パターン を一度で記憶し，かつすず忘れないようにするた め, 通常は $2 \sim 5$ 程度の值を用いる。またcは, 重み $w_{i j}$ の忘却の際の変化特性を決める正定数であり, 通 常 100 程度の值をとる。これらの值は予備実験により 定めた。また，これらの值は結果にほとんど影響を与 えず，提示するパターンのいかんにかかわらず一定で よいことも確かめた。従って，本モデルでは，実質的 には調整すべきパラメータの数は，先に述べた類似度 $s$ と忘却定数 $\alpha$ のつだけである。

ネットワークの学翌は, 串ず(5)式により入力層一 出力痼間重み $w_{i j}$ の更断を行う。( 5 ) 式右辺第 1 項は 学習前の重みの值を減少させる項で, $\alpha g\left\{\theta_{j}(t)\right\}$ の割 


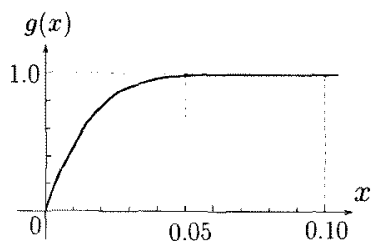

図 3 関数 $g(x)$ の久出力特性 $(c=100$ のとき)

Fig. 3. Characteristics of $g(x)$.

合だけ小さくする。ここで(6)式は，忘却の際の重子 $w_{i j}$ の減少量を決める関数であり，図 30 ような入出 力特性がある。ある出力層ユニット $j$ に対して、末学 習状態や忘却状態が続くと，ュニットの出力 $\delta_{j}=0$ で あり，また，(5)式右辺第 1 項により，重みベクトル の大きさは小さくなり，従って（7)，(8)式より增幅 率 $A_{j}=$ BOUNDである。よって，(10)式によりしき い值 $\theta_{j} \doteqdot 0$ なので, $g\left(\theta_{j}\right) \fallingdotseq 0$ となる。一方, 学習状態 では $\theta_{j} \gg 0$ であり, $g\left(\theta_{j}\right) \fallingdotseq 1$ となる。

(5) 式右辺第 2 項怙提示さ机たパターンの学習頊で あり，出力層間で競合に勝ったュニット，すなわち出 力 $\delta_{j} か ゙ \delta_{j}=1$ であるユニットだけが有効となる項で ある。このユニットに結合する重みに刘して，提示パ ターンの対応する値 $I_{i}$ をとのま加え合せ, 新しい 重み $w_{i j}(t+1)$ とする。（5)式には，同じパターンを 何度も提示吉ると, 重み $w_{i j}$ が徐々に強化されてパ夕 一ンを忘れにくくなる，という特性がある。またあ るパターンを学習した後に，それに少々ノイズの加わ ったパターンを提示したとする。このとき，既に重み が多数回の学習により強化されていれば，ノイズを含 んだパターンを重みに加えても，その影響は相対的に 低下するようになっている。

次に(7)式に上り, 出力層ュニットの入力增幅率 $A_{j}$ を更新する。新しい堌幅率 $A_{j}(t+1)$ は前の状態 $A_{j}(t)$ に依存せず，(9)式のように更新された入力層一 出力層間の重み $w_{i j}(t+1)$ だけに依存する。重み $w_{i j}$

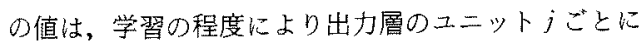
異なるため，入力層にパターンを提示したとき，出力 層の各ユニットへ入る信号量も異なる。そこて, 增楅 率 $A_{j}$ を，重み $w_{i j}(t+1)$ により決定することにより, 出力層のユニットへの入力信号量を適正化している。 増幅率 $A_{j}$ の值は, 入力層一出力層間の重みベタトル $W_{j}$ の大きさ逆数であり, 重みぶタトルW さが小さいほど，增偪率 $A$ 、逆に大きくなる。ただ し增幅率 $A_{j}$ の值には，(8)式の関数 $h(x)$ によ上 限值 BOUND がある。関数 $h(x)$ の入出力特性を図 4 に示す。

電学論C, 113 巻 6 号, 平成 5 年

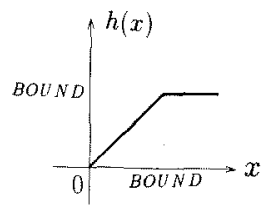

图 4 関数 $h(x)$ の入出力特性

Fig. 4. Characteristics of $h(x)$

最後に，(10)式により出力層のユニットのしきい值 $\theta_{j}$ を更新する。しきい值 $\theta_{j}$ は, 学習状態では常に類 似度 $s$ に固定されるが，末学涡状態または忘却状態に 标いて入力信号增幅率 $A_{j}$ が上限值 BOUNDになっ ていて，かつユニットの出力が $\delta_{j}=0$ であるときに，

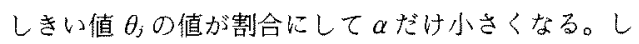
きい值は、記憶されているパターンとの類似度を判断 する役割をもつ。すなう，既に記憶しているパター ンと入力層に提示されたパターンとが類似であると判 断され机ば，コニットの入力はそのまま通過するが， そうでないと判断されれば入力は通過しないようにな っている。

学習による重みやしきい值の変化を大まかに説明す ると, 学習状態, 忘却状態のいかんにかかわらず, パ ターンの記憶の度合により重み $w_{i j}$ 洨增减する。また 学習状態では, 増幅率 $A_{j}$ が変化し, しきい值 $\theta_{j}$ は 固定されるが[(8)式上，(10)式下]，末学習状態また は忘却状態では，しきい值 $\theta_{j}$ のほうが変化し，增幅 率 $A_{j}$ は固定される〔(8)式下，(10)式上)。この境界 が堌䚡率 $A_{j}=\mathrm{BOUND}$ である。

〈4・2〉ネットワークの初期状態 ネットワーク の初期状態では重みベクトルW, の要素 $w_{i j}$ の值をう ンダムに，かつベクトルの大きさ非常に小さな正の 值に㽼ろえて扔く。これは，入力層にパ夕ーンが提示 されたときに出力層に信号を伝搬する必要があり，一 方学殠の際に初期状態の影響が残るの活好ましくない ためである。実験では重みべクトルの大きさを 0.001 とした。予備寒騃により、この程度の大きさにする と，上述の要件を満たすことを確認した。入力パター ンは大きさ1に規格化するため，どのような对象に対 してもこの数值は有効であると考えられる。

また，増幅率 $A$ ，の值も一定值 BOUNDにそろえ る。更に, 出力層のユニットのしきい值 $\theta_{j}$ の值を0 にしておく。すなわち等習前には、ネットワークの入 力層一出力層間の重み $w_{i j}$, 出力層のュニットjの入 力信号增幅率 $A_{i}$ ， しきい值 $\theta_{j}$ を次の上うに初期化す る。

重孙 $w_{i j}$ 
for $\forall j, w_{i j}:$ ランダム

$\left|\boldsymbol{W}_{j}\right|:\left|\boldsymbol{W}_{j}\right|=0.001$ 程度

增幅率 $A_{j}$

for $\forall j, A_{j}=$ BOUND

しきい值 $\theta_{j}$

$$
\text { for } \forall j, \theta_{j}=0
$$$$
\text { ここで, } \boldsymbol{W}_{j}=\left(w_{1 j}, w_{2 j}, \cdots, w_{n_{j}}\right)
$$

《4・3〉 忘却について 忘却の目的は, ネットワ 一クのユニットや重みの有効利用にある。一度学習し たパターンでも，その後同様のパターンが提示されな ければ，ネットワークにとってはそれは必要のないパ ターンになってしまう。ネットワークのユニットや重 みは有限であり，ほとんど提示されないパターンをい つまでも覚えていることはむだである。そこで，この ようなむだなパターンは忘れるようにし，そこへ新し いパターンを学習できるようにすれば，ネットワーク は常に必要なパターンだけを記憶し、ネットワークの もつ“記憶容量”も有効に利用できると考えられる。

この動作を実現するためには, ある出力層のユニッ ト、およびそれに付随する重みなどが何らかのパター ンを記憶していたとして, それを忘れた後に, 同じユ ニットや重みにそれまでとは別のパターンが入ってき たときに，それを記憶できる必要がある。

一方, 忘却の概念を導入するには, 学習したハタター ンをどの程度記憶しているか, という“尺度”が必要 である。この“尺度”は, 本ネットワークでは, 重み $w_{i j}$ を用いている[(5), (6)式]。すなわ方, 重み wijの值が大きいほど, 学習したパターンを明確に覚 えているということである。

ホットワークが忘却を行うためには, 重み称 の值 を徐々に小さくすればよいことになる。しかし，重み の值を小さくすると出力層のユニットへの入力信号量 が娍少するため，しきい値が大きいままであると，ュ ニットへの入力值がしきい值を超えられないことにな る。この闍題を解決するために，本ネットワークでは しきい值 $\theta_{j}$ の值を小さくして信号量がしきい值を超 亲られるようにする方法を採用している。

ただし，忘却状態においてしきい值 $\theta_{j}$ を減少させ る際には次のような制約が存在する（式の導出につい ては付録参照)。

$$
\begin{aligned}
& \text { BOUND }\left\{-\left(1-s^{2}\right)+s \sqrt{s^{2}+\left|\boldsymbol{W}_{j}\right|^{2}-1}\right\} \\
& \quad \leqq \theta_{j} \leqq \text { BOUND } s\left|\boldsymbol{W}_{j}\right| \cdots \ldots \ldots \ldots \ldots \ldots
\end{aligned}
$$

学習アルゴリズム〔(5)〜(10)式〕において，(6)式 の定数 $c$ を〈4・1〉節で述べたように100程度にとれ ば, $\theta_{j} \geqq 0.1$ の範囲では(14)式の上限である $\theta_{j}=$
BOUND $s\left|\boldsymbol{W}_{j}\right|$ を維持しながら忘却が進んでいき， $\theta_{j}$ $<0.1$ になると重みの忘却の割合が隇少して新しいパ ターンに反応しやすくなる。

\section{5. 計算機実験}

本章では，提案するニューラルネットワークの特徵 である, 適応的学習と忘却に関する㬰験を行い, その 有効性を検証する。

〈5・1〉 学習に関する実験 本節ではネットワー クの有する特徵のうち, 適応的学習に関する実験につ いて説明する。ここでは，提示されたパターンをネッ トワークが逐次記憶・分類していく樣子を示す。

実験に用いたパターンは，入力が 20 次のアナログ パターン 50 個である。これらのパターンは，ネット ワークに提示する前に正規化され，それぞれ一度だけ 任意の順番でネットワークに提示した。実験に用いた ネットワークは，入力層のユニット数は提示パターン の次数から 20 個, 出力層のユニット数は, ネットワ 一クが入力パターンのすべてを異なるカテゴりーに分 類した場合でも不都合が生じない数として，50 個と した。また, 学習の際のパラメー夕は, 忘却定数 $\alpha=$ 0 , 堌幅率の上部 $\mathrm{BOUND}=2.0$, 忘却の変化特性を 定めるパラメータ $c=100$, また類似度 $s$ 注 $s=0.90$ と $s=0.95 の 2$ 通りとした。

実験結果を $5($ a $)(s=0.90),($ b $)$ 図 $(s=0.95)$ に示す。各パターン図は，横軸に入力ユニット，縦軸 にその値をプロットして, 各点を直線で結んだもので ある。また図中の番号が出力層の一つのユニットに対 応していて, 番号の下のパターンがそのユニットへ分 類されたことを表している。

図 5 上り，全般に類似形のパターンが同一のユニッ トに分類されていることがわかる。特に，パターンの ピーク部分（值の大きい入力部）が同じパターンは, 同じュニットに分類されていて，逆にピーク部分が一 つでもずれているパターンは別のユニットに分類され ている[例：(a)图のユニット10 とユニット19], こ れは, 出力層のニニットへの入力が, 重みと提示バ夕 ーンの内積に依存するためである。

また, 少々の凹凸(ノイズ)があっても，全体の形が 似ているパターンどうしも同じュニットに分類されて いる(例：(a)図のユニット7やユニット9\}。従っ て, 学習の初期にはノイズを含まないパターンを多数 回ネットワークに提示して重みを強化して打忖，後 でノイズを含むパターンを提示しても同じユニットが 反応するようになると考えられる。

図 5 (a)と(b)とでは, 分類されたクラス数が異な 

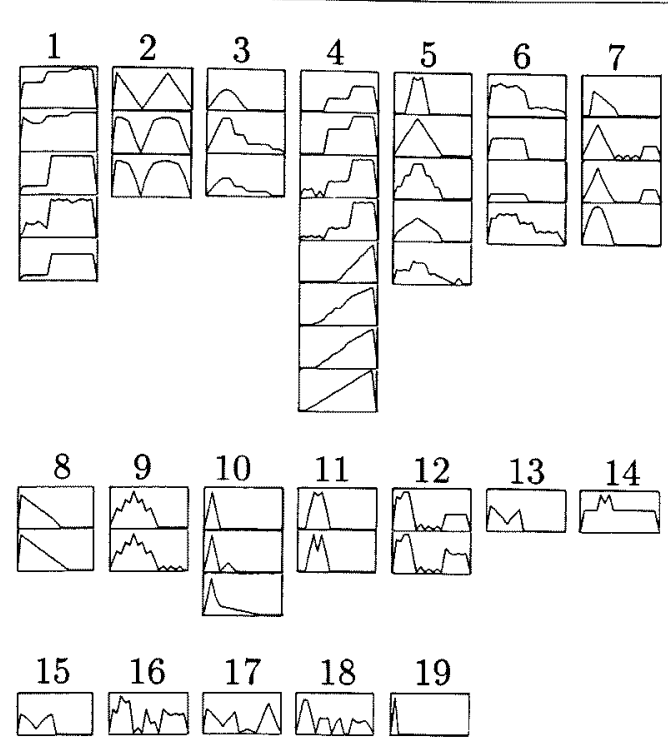

(a) $s=0.900$ と
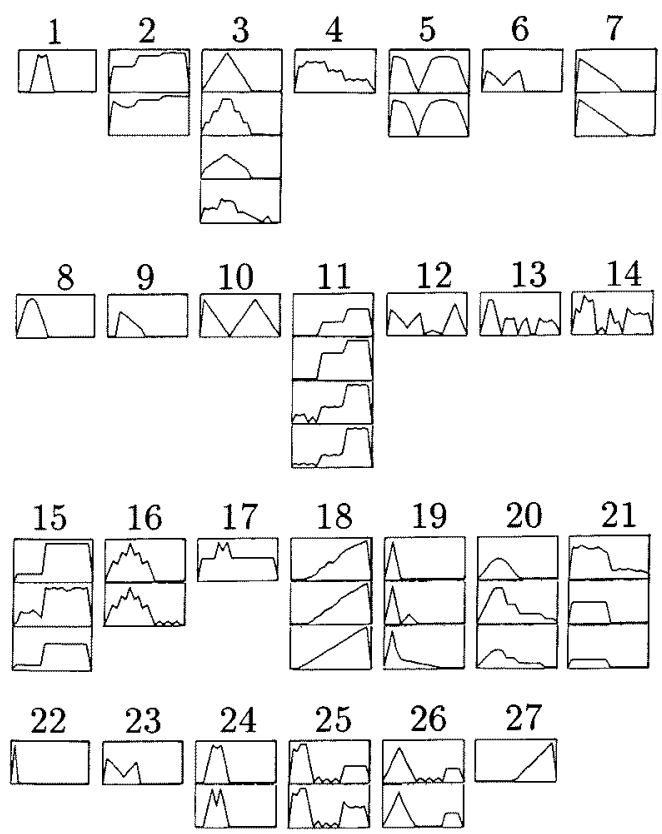

(b) $s=0.95$ のと

図 5 クラス分類結果

Fig. 5. Classification of patterns. っている((a)図は19クラス，(b)図は27クラス)。 特に，(b)図では分割されたクラスが，(a)図では同 一のクラスになっているものが存在する。これは学習 時，類似度 $s$ の值が異なるためで，〈4・1〉節で述べた ように，類似度 $s$ の值が大きい活ど学習パターンを多 くのクラスに分割するからである。

〈5・2〉忘却に関する実験＼cjkstart本節では，ネットワ ークがュニットの有効利用を行えるかどうか，すなる ち、ネットワークが一度学習したパターンを忘れた後 で, 新しいパターンの学習が可能かどうかを検証する。

ここでは以上のことに着目するために，むやみに不 必要なユニット数の使用を避け〈5・1〉節の実験で用 いたパターンのうち 3 個を用意し，それらを数種類の 提示方法でネットワークに提示して記憶させる実験で ある。

実験に用いたネットワークは，入力層のユニット 20 個, 出力層のユニット3 個からなり, 学習の際の パラメータは, $s=0.95, \alpha=0.01, \mathrm{BOUND}=2.0, c$ $=100$ とした。パターンの提示方法は, 以下の 3 種類 である。

〔方法 1 ] 時刻 1 にパターン1, 時刻 2 にパー ン 2 , 時刻 3 にパターン 3 をそれぞれ提示する。この 提示順序を 200 時間ステップごとに繰返す。そのほか の時刻には何も提示しない。

[万法 2]時刻1にパターン1，時刻2にパター ン 2 をそれぞれ提示する。その後，パターン 2 を 100 時間ステッごとに，パターン 1 を 500 時間ステップご とに再提示する。一方，パターン 3 は時刻 401 に初め て提示し, 以後 500 時間ステップごとに再提示する。

〔方法 3〕時刻 1 にパターン 1, 時刻 2 にパー ン 2 をそれぞれ提示する。その後，パターン 2 を 100 時間ステップごとに再提示する。その後, 時刻 1001 にパターン 3 を初めて提示し, 続けて時䘞 1002 にパ ターン 1 を再提示する。

ここで，1時間ステップとは，パターンをネットワ ークに提示してから，そのパターンの学習が終了する まで，すなわち，重みやしきい值を修正するまでの時 間をいう。また，学習の前のネットワークの初期状態 は方法 1〜3すべて同一とした。

実験の結果を図6(a)〜 ( c )に示す。図中，横軸は 時刻, 䋛軸は出力層のユニットの内部活性值である。 各図は，その時刻の学習が終了した後，もし $1 \sim 3 の$ 各パターンを提示したら，そのときのネットワークの 出力層のユニットの内部活性值がどのようになるかを 表している。すなわち，その時刻で各パターンがどの ユニットにどの程度記憶されているかを示している。 

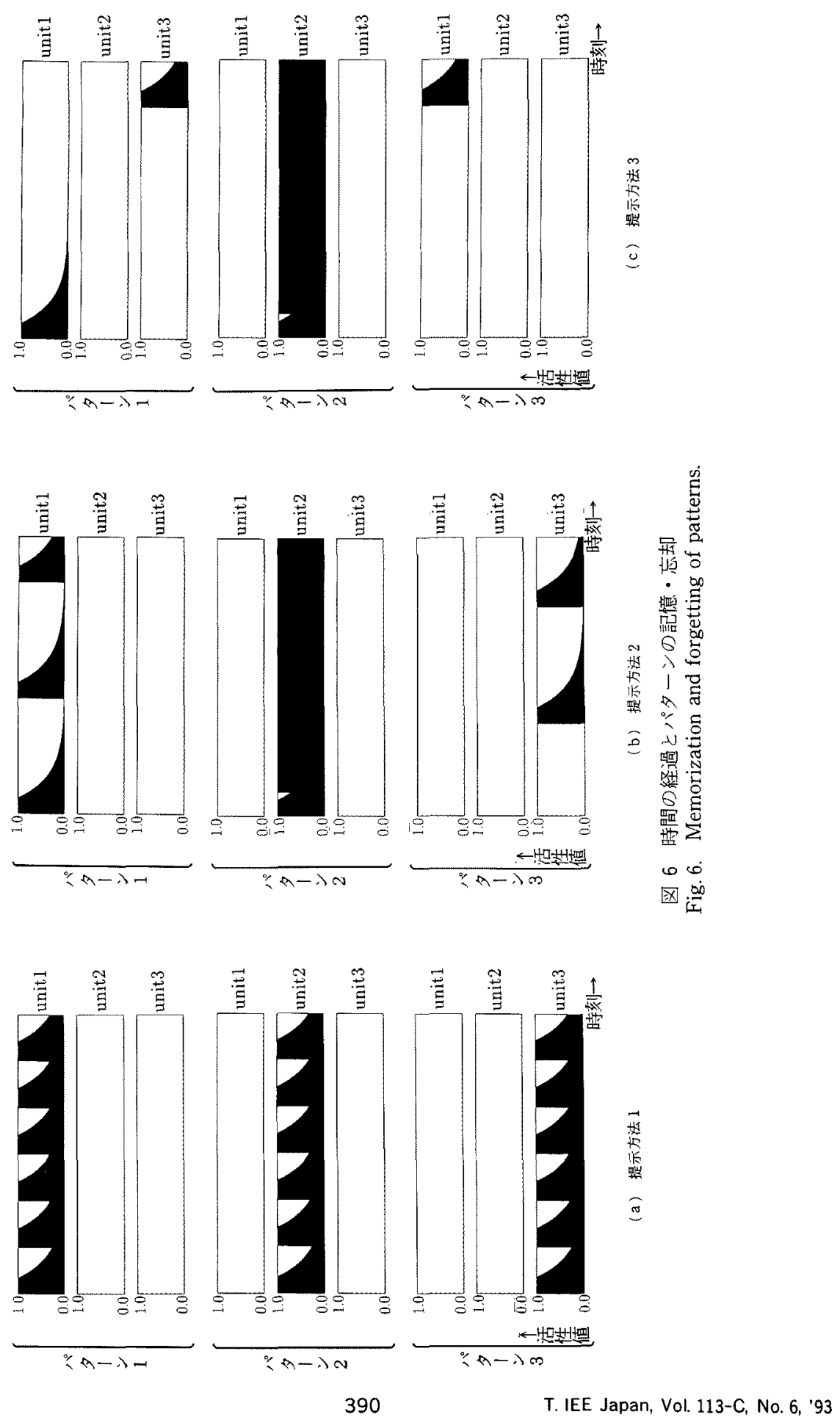
まず方法1では，(a)図より，パターン1〜3が】 回の提示でそれぞれコニット1〜3に記憶されている ことがわかる。しかし，時刻 80 を過ぎたあたりから 徐々にパターンを忘れ始めてゆく。ところが，時刻 201 からまたうつのハターンを順番に提示すると, 記 憶を取り戻すようになる。その後は，忘れかけては覚 える，の繰返しである。

次に方法2であるが，(b)四よりまずパターン1， 2 がや伎り1回の提示でそれぞれユニット1，2に記 憶されている。パターン 2 は 100 時間ステップに 1 回 の割合で提示され続けているので，一度は忘れかける が，ての後は重みが强化されていき，ニニット2では 安定した内部活性值加出ている。一方，パターン1は その後しばらく提示されないため，パターン忘れて いく。しかし，時刻401にパターン3提示した時点 では，ユニット1 1 はまだわずかにパターン 1 を覚えて いる。そのため，パターン 3 はュニット 3 に割当てら れる。その後, 時刻 501 でパターン 1 を提示すると, ユニット1はパターン1の記憶を回復し, 結局パター ン1〜3はそれぞれ方法 1 と同じュニットにパターン を記憶した。

最後に方法 3 は，（c)図を見ると，方法2上同様に パターン1，2がやはり1回の提示で癸れぞれニニッ 卜 1,2 に記镱されている。パターン 2 が定期的に提 示されるので，コニット2の内部活性值が安定してい る点も方法 2 と同じである。しかし，時刻 1000 まで パ夕ーン10提示がないため、ュニット1はパターン 1 をとんど忘れている。そのため，時刻1001にパ ターン 3 を提示すると，コニット3ではなく、コニッ 卜1に記憶される。これは，忘却した重み(この場含 はュニット1の重み)のほうが未学習の重み(ユニット 3の重み)上りも大きいためである。次の時刻 1002 でパターン 1 を提示すると、ユニット 1 にパターン 3, ニニット 2 にパターン 2 がそれぞれ記憶されてい るので，パターン 1 は結局ユニット3に記憶される。

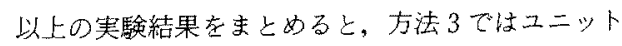
1 がパターン 1 を記譩しても，その後長時間にわたり パターンの入力がないため，コニット1が反応するこ とがなくる（出力が常に0），ネットワーク全体か ら見ると、これはユニットの效率的利用とはいえず,

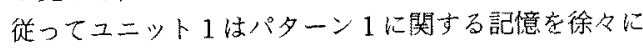
忘却し，適応的に別のパターン3党記憶してそれに対 して反応するようになる。逆に方法 1，2では記憶か 少しでも残っていれば，かなり以前に入力されたパ夕 ーンに対しても，記憶を回復することを示している。 記憶心回復は以下のように考えら机る。学猊アルゴ

電学論C, 113 巻 6 号, 平成 5 年
リズム((5)〜 (10)式了により，忘れかけているパー ンを記憶している出力ユニットjは，その忘れかけた パターンの提示により, 最大限の増幅率で力信号を 受け取る[(7)，(8)式〕を机に対して，他のパタ一 ンを記憶している他のニニットの入力信号の増楅率 は，はるかに小さい。また，ユニットjのしきい值は ほ悉0である〔(10)式了のに対し，他のニニットは大き さ $s$ 障壁がある。更に, 内部活性値の大きさは, 入 カパターンベクトルと重みバクトルの内積で决まるた め, 両者の向く方法が近い保ど大きい。結局，忘れか けたパターンの再入力に対して，これを党えていたユ ニットjが競合に勝ち，記憶の回復になる。

パターン1〜3を，それぞれ別の力テコリーを代表 するべタトルと考えれば，〈5・1〉節の寒験結果より， 同じカテゴリーに属する入力パターンに対しては同じ 出力ユニットが反応することから，入力パターン数や 出力パターン数が多数ある場合においても，あるカテ ゴリーに属する入力パターンが長時間提示されなけれ ば，そのカテゴリーを記憶しているュニットのそのカ テゴリーに対する記億は弱まるが, 再びそのカテゴリ 一に属する入力パターンが提示されれは，即座に記憶 をとりもどすと解瀵できる。また，完全に忘却してし ま光ば，その出力ユニットは全く別のカテゴリーに属 する入力パターンに反応するようになり、ニニットは 適応的に再利用されることになる。

\section{6.むすび}

本論文では，従来とは哄なる手法により適応的にパ ターンの記镱・忘却を行う新しいニューラルネットワ 一クを提案した。このネットワークは，従来の教師な しニューラルネットワークとほほ同等の動作を有しな がら構造や動作が簡単であり，パターンの記憶を逐次 高速で行うことができる。また，あまり提示されない パターンを忘却し，新しいパターンを記憶することも 可能であり、これらの性質を計算機実験により検証 し，その有効性を確加めた。

本論文で提案したネットワークの学習では，しきい 值は忘却時以外には固定となっているが,これを外界 の教師により変化させて、より高度な適応学習につい て考察することが命後の課題である。

(平成 4 年 11 月 4 日受付, 同 5 年 3 月 16 日再受付)

\section{文献}

(1) S. Grossberg: Neural Networks and Natural Intelligence (1988) The MIT Press

(2) G.A. Carpenter \& S. Grossberg: "ART2; selforganization of stable category recognition codes for 
analog input patterns", Appl. Opt., 26, 4919 (1987)

（3）山内康一郎・神保茟志・梅野正義：「新奇パターンを学習す

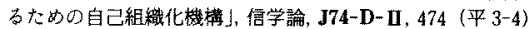

(4) D.E. Rumelhart, G.E. Hinton \& R. J. Williams: Paralle Distributed Processing (1986) The MIT press

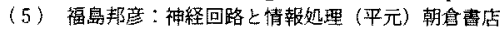

（6）中野 㢣編著：ニューロコンビュータの基礎（平2）コロサ 社

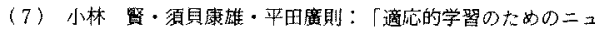
ーラルネットワークj, 信学技報, NC92-8.57 (平4)

\section{付 録}

(16) 式の導出

忘却状態においてしきい值 $\theta_{j}$ 老隇少させる際には， 上限と下限の制約があ。

まず，下限について説明する。いま，出力層のユニ ット $j$ が忘却状態であるため，A＝BOUNDである。 ここで，入力層にパターン $I$ (ベクトル) 提示す る。このとき, 出力層のユニット $j$ への入力值 $O_{j}^{\mathrm{n}}$ は,

$$
O_{j}^{\text {!n }}=\text { BOUND } \boldsymbol{W}_{j} \boldsymbol{I}
$$

である。この入力值 $O_{j}^{\mathrm{n}}$ がしきい值 $\theta_{j}$ を超えている （または等しい）と仮定する。すなわち，（付 1)式か ら,

$$
\theta_{j} \leqq O_{j}^{\text {in }}=\mathrm{BOUND} \boldsymbol{W}_{j} \boldsymbol{I}
$$

である。従って, ユニットjの内部活性值も $O_{j}^{\text {act }}=$ BOUND $\boldsymbol{W}_{j} \boldsymbol{I}$ である。ここで，このユニットが競合 に勝ち、パターンIを学習したとする。簢単のため, 忘却定数 $\alpha$ を無視すると，新しい重み $\boldsymbol{W}_{j}^{N}$ ，出力層の ユニットのしきい值 $\theta_{j}^{N}$ は（7)，(12) 式から，

$$
\boldsymbol{W}_{j}^{N}=\boldsymbol{W}_{j}+\boldsymbol{I}, \theta_{j}^{N}=s
$$

となる。学習後にパターンIを再度提示したときに は，同じュニットが反応する必要がある。すなわち， 出力層のユニットへの入力のほうが，しきい值よりも 大きくなけ机ならない。しかし，いま，しきい值の ほうが大きいと仮定する。この状態を数式で表すと，

$$
O_{j}^{\text {ln }}=A_{j}^{N} \boldsymbol{W}_{j}^{N} \boldsymbol{I}=\frac{\boldsymbol{W}_{j}^{N} \boldsymbol{I}}{\left|\boldsymbol{W}_{j}^{N}\right|}=\frac{\left(\boldsymbol{W}_{j}+\boldsymbol{I}\right) \boldsymbol{I}}{\left|\boldsymbol{W}_{j}+\boldsymbol{I}\right|}<\theta_{j}^{N}=s
$$

となる。（付 4)式に搔いて，

$$
\begin{aligned}
& \left(\boldsymbol{W}_{j}+\boldsymbol{I}\right) \boldsymbol{I}=\boldsymbol{W}_{j} \boldsymbol{I}+1 \\
& \left|\boldsymbol{W}_{j}+\boldsymbol{I}\right|=\sqrt{1+\left|\boldsymbol{W}_{j}\right|^{2}+2\left(\boldsymbol{W}_{j} \boldsymbol{I}\right)}
\end{aligned}
$$

であるので（付5)，(付6)式を(付 4) 式に代入して， 両辺を二乗して変形すると,

$$
\left(\boldsymbol{W}_{j} \boldsymbol{I}\right)^{2}+2\left(1-s^{2}\right)\left(\boldsymbol{W}_{j} \boldsymbol{I}\right)+\left\{\boldsymbol{1}-\mathrm{s}^{2}\left(1+w^{2}\right)\right\}<0
$$

となる。ただし，

$$
w=\left|\boldsymbol{W}_{j}\right|
$$

である。これを $\boldsymbol{W}_{j} \boldsymbol{I}$ に関する二次不等式と見て解く と,

$$
\begin{aligned}
-\left(1-s^{2}\right)- & s \sqrt{s^{2}+w^{2}-1} \\
& <\boldsymbol{W}_{j} \boldsymbol{I}<-\left(1-s^{2}\right)+s \sqrt{s^{2}+w^{2}-1}
\end{aligned}
$$

となるが， $\boldsymbol{W}_{j} \boldsymbol{I}>0$ のため，

$$
0<\boldsymbol{W}_{j} \boldsymbol{I}<-\left(1-s^{2}\right)+s \sqrt{s^{2}+w^{2}-1}
$$

が適解である。ここで（付 2) 式を変形すると，

$$
\boldsymbol{W}_{j} \boldsymbol{I} \geqq \frac{\theta_{j}}{\mathrm{BOUND}}
$$

であり，これと(付 10)式から，

$$
\theta_{j}<\text { BOUND }\left\{-\left(1-s^{2}\right)+s \sqrt{s^{2}+w^{2}-1}\right\}
$$

となる。すなわち，しさい值 $\theta_{j}$ は(付 12) 式の範囲外 にあればよいことになる。従って，

$$
\theta_{j} \geqq \operatorname{BOUND}\left\{-\left(1-s^{2}\right)+s \sqrt{s^{2}+w^{2}-1}\right\}
$$

が忘却時におけるしきい值 $\theta_{j}$ の下限を定める式であ る。（付 13）式において，s を固定したときの $w と \theta_{j}$ との関係を付図1に示す。

なお，(付 13)式で $s^{2}+w^{2}-1<0$ の場合に $\theta_{j}$ は虚 数となるが, $s^{2}+w^{2}-1=0$ のと（付 13)式は，

$$
\theta_{j}=-\mathrm{BOUND}\left(1-s^{2}\right)
$$

となる。すなわち（付 14）式が $\theta_{j}$ の定義域となる。 しかし, BOUND >0, $0<s<1$ なので，(付 14)式の 右辺は負であり， $\theta_{j}$ は本ネットワークでは $\theta_{j} \geqq 0$ であ るため，この定義域の制約は受けない。

次に上限について説明する。学習状態では,出力漛の ユニットは, 重みべクトル $\boldsymbol{W}_{j}$ と角度にして $\cos ^{-1} \theta_{j}$, すなわち $\cos ^{-1} s$ 以内の方向にあるパターンベタトル

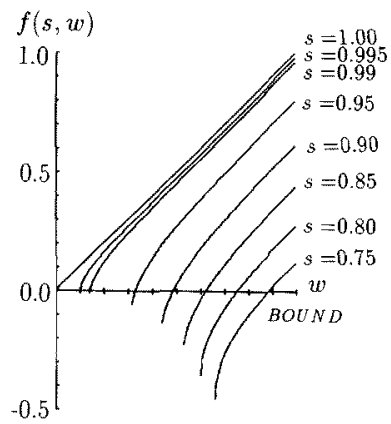

付図 1 (付 13) 式の特性 ( $s$ を固定) app. Fig. 1. Characteristics of Eq. (app.13). 
Iが提示されたときに内部活性值をもつようになって いる (本文 $\langle 4 \cdot 1\rangle$ 節参照)。しかし, 忘却状態において この特性が失われるのは好ましくない。忘却状態で は, ネットワークにパターンIを提示したときの出 力層のユニット $k$ への入力值は(付 2 ) 式のようにな る。いま, 提示したパターンベクトル I が, 重みべ クトル $\boldsymbol{W}_{j}$ と角度にして $\cos ^{-1} s$ だ離れていたとす る。このとき, ユニット $j$ への入力值 $O_{j}^{\ln }$ は,

$$
O_{j}^{\text {in }}=\operatorname{BOUND} \boldsymbol{W}_{j} \boldsymbol{I}=\mathrm{BOUND}\left|\boldsymbol{W}_{j}\right|_{s}
$$

$$
(\because|\boldsymbol{I}|=1) \cdots \cdots \cdots \cdots \text { (付 } 15)
$$

となる。この入力值がしきい值 $\theta_{j}$ を超えなければな らない。すなわち,

$$
\theta_{j} \leqq O_{j}^{\ln }=\text { BOUND } s\left|\boldsymbol{W}_{j}\right|
$$

が忘却時におけるしきい值 $\theta_{j}$ の上限を定める式であ る。

従って,（付 13) 式と(付 16) 式から $\theta_{j}$ の值は,

$$
\begin{aligned}
& \operatorname{BOUND}\left\{-\left(1-s^{2}\right)+s \sqrt{s^{2}+\left|\boldsymbol{W}_{j}\right|^{2}-1}\right\} \\
& \left.\leqq \theta_{j} \leqq \text { BOUND } s\left|\boldsymbol{W}_{j}\right| \cdots \cdots \cdots \cdots \text { (付 } 17\right)
\end{aligned}
$$

の範囲にある必要がある。

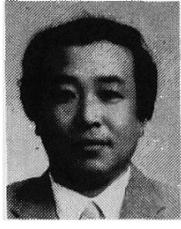

\section{須 貝 康 雄 (正員)}

昭和 60 年東京工業大学大学院理工学 研究科情報工学専攻博士課程修了。61 年千葉大学工学部助手, 平成 3 年同助教 授, 現在に至る。工学博士。大規模シス テムの最適化，およびニューロコンピュータなどの分散シ ステムの研究に従事。

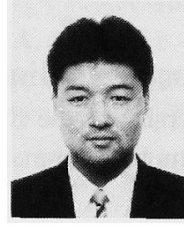

小林賢 (非会員)

平成 4 年干葉大学大学院工学研究科電 子工学専攻修士課程修了, 同年(株)日立 製作所システム開発研究所入社, 現在に 至る。ニューラルネットワーク, 交通シ ステムの研究に従事。 